\title{
If all planning is local, how are we going to save tomorrow? Ten pragmatic lessons from the field
}

\author{
Ann Hope Ruzow Holland ${ }^{1,2,3}$ \\ Accepted: 15 June 2021 / Published online: 23 July 2021 \\ (c) AESS 2021
}

\begin{abstract}
This monograph presents practical lessons learned from more than 40 years of professional and academic experience in ecological and community land use planning within the New York's Adirondack-Champlain-Catskills Regions, the Northern Forest of Maine, Vermont, New Hampshire and New York, and the Northern Appalachian/Acadian Ecoregion. The intention is to share catalytic, synergistic, and interdisciplinary field lessons from the author's firsthand experiences for the benefit of renaissance communities, researchers, and practitioners seeking new beginnings and stimulation of new thinking beyond their sightlines. Lessons are presented in ten areas [1] integrating legal, ethical, and natural considerations; [2] recognizing diverse types of land ownership; [3] discovering shared ethics and values; [4] modernizing planning practice; [5] using Participatory Action Research (PAR); [6] working with limited access to science, technology, and planning resources; [7] using science to inform and enlighten the planning process; [8] riding the coattails of popular movements; [9] recognizing human relationships with natural environments; and [10] educating and informing citizens as a force for nature. These ten lessons, contextualized within Critical Theory and Participatory Action Research (PAR), lead the author to an "inflective" PAR paradigm for land use planning that links planning, participation, and science. Perhaps, just perhaps, through a shared context of place-tomorrow can be saved.
\end{abstract}

Keywords Land use planning · Participatory action research · Critical theory · Environmental science · Adirondacks · Northern forest $\cdot$ New York State $\cdot$ Landscape ecology

\section{Introduction}

"Making better places" through place-making is a humanbased endeavor that weaves together the threads of history, law, and contemporary and cultural norms regarding nature, ethics, esthetics, property, and community (Palermo and Ponzini 2015, p.3). Ideas and perceptions about natural environments intersect directly with the role of physical place in quality of life and the value or importance placed on the "home territory" (Brown and Raymond, 2007; Lien, 2009; Firouzmakan and Daneshpour, 2015). In recent times,

Ann Hope Ruzow Holland

aholland@grantplanact.com

1 Professional Planning Consultant, Willsboro, Essex County, NY, USA

2 Adjunct Faculty-Research Scholar- Environmental Studies, Antioch University New England, Keene, NH, USA

3 Adjunct Faculty-SUNY Plattsburgh Geography, Political \& Environmental Sciences, Plattsburgh, NY, USA rapid land use and global environmental change have literally come home to roost, exposing residences, families, and communities to disruptive weather events, loss of ecosystem services, invasive species, and conflicting land uses (Pursuwani, et al., 2020). Powerful and cumulative changes in climate and land use, interest in Environmental Justice and equity, have now combined with the public health crisis associated with the COVID-19 Pandemic (Salas et al. 2020; Watson, et al., 2020). These circumstances focus further attention on place-homes, neighborhoods, and communities. Making places better through a deliberate, inclusive, and collaborative process is more important than ever. People are not immune to, nor willing to ignore the significant impact that environmental and human-induced changes have on the drinking water, air quality, property, and protected landscapes (Lien, 2009).

This monograph summarizes and presents a handful of comprehensive lessons learned from a lifetime of personal, professional, and academic experiences within the New York's Adirondack-Champlain-Catskills Regions, the 
Northern Forest of Maine, Vermont, New Hampshire, and New York, and the larger Northern Appalachian/Acadian Ecoregion contextualized within a community-of-practice associated with Participatory Action Research (PAR) and critical theory.

I am fortunate that my backyard and home territory includes New York's Adirondack, Lake Champlain, and Catskill Regions. These geographic and political designations are populated living landscapes that also have globally important, ecologically significant, biologically diverse, extensive tracts of intact boreal forests, and critical water resources. Greater in size than Yellowstone, Everglades, Glacier, and Grand Canyon National Parks combined, the Adirondack Park is the largest protected area within the Northern Appalachian/Acadian Eco-Region and within the contiguous USA. The Lake Champlain watershed partially overlaps with the Adirondack Park and is shared between New York, Quebec, Canada, and Vermont. Lake Champlain is considered the 6th Great Lake and encompasses 8234 square miles of surface water, wetlands, forests, farms, and communities (Lake Champlain Basin Program, 2021). Less than 130 miles to the south of the Adirondack Park is the 700,000-acre Catskill Region. The Catskills include another mixture of public and private lands and small communities between Albany and New York city, NY that collectively supplies New York city with its drinking water (Catskill Watershed Corporation, 2021).

Both the Adirondacks and the Lake Champlain Region are also part of the Northern Forest Region which includes northern Maine, New Hampshire, Vermont, and New York. This larger region is home to more than two million people who live in rural communities, larger towns, and small cities surrounded by the largest intact forest in the eastern US (Northern Forest Center, 2021). At an even larger scale, the Adirondacks, Lake Champlain Watershed, and the Northern Forest are nested within the Northern Appalachian-Acadian Ecoregion. The common thread for all these designations is the forest resources. The Ecoregion encompasses the most intact temperate broadleaf forest remaining in the world and stands out in eastern North America as a center of climate resilience (Two Countries and One Forest (2021)).

My diverse and extensive work in community and regional planning provides me with broad and deep lived experiences collaborating with the people and communities residing, and visiting, this natural resource-rich, internationally recognized geography. There is limited space in this monograph to supply granular examples of the dozens of projects, regional, watershed, and local land use plans and ordinances, Scenic Byways, Main Street, infrastructure, recreation, hazard, and disaster mitigation activities, at all scales, which informed my lessons. Similarly, it was not my intention in this paper to compare my experiences to those in other geographies where I have not worked. This monograph is NOT a comparative analysis or comparative case study with places such as Lake Tahoe or the Columbia River Gorge. My only intention is to share my "big" lessons-those that are catalytic, synergistic, and interdisciplinary-with renaissance communities, researchers, and practitioners seeking validation of their work, new beginnings, and stimulation of new thinking beyond their sightlines. My revelations may not be shiny and new, but tradition is borne of habit and not necessarily novelty. And perhaps, just perhaps, through a shared context of place-tomorrow can be saved.

\section{Contextualizing the lessons within a theoretical framework: lived experience, dialogue, equity, action, and change}

A brief, contextual understanding of the theoretical framework that informs the author's lessons learned provides a useful introduction to the monograph. It is not the intent of this paper to conduct a full historical review or a comparative theoretical analysis of the roots of PAR, Critical Theory, or Social Change Theory-or the individual philosophies of the noted persons. This monograph does not pretend to supply an exhaustive discussion of the entire PAR ancestral list in its use in landscape planning, land use planning, environmental justice, community engagement, etc. Many researchers have written on these subjects in the twenty-first st century and many more will do so in the years to come. The author acknowledges that limited and specific PAR literatures associated with landscape planning were published in 2011 (Brown, 2011; Carlson et al., 2011; Chanse, 2011; Schoth et al., 2011; Thering, 2011; and Thering and Chanse, 2011). My work and research focus on place-making where power differentials (oppressor and oppressed) exist or where educational and organizational venues align closely with traditional PAR settings.

The theory, research, and practice of land use and landscape planning are not based upon a codified and unified system of thought. Instead, they are based upon multiple and diverse viewpoints that coexist and support persistent and lively competitive interaction among theorists and academics (Fainstein, 2005; Ferreira, et al., 2009). Planning is alive, vibrant, and contentious (Healy, 1992; Ferreira, et al., 2009; Fainstein, 2005). Some academics focus on the concepts of democracy, collective action, economic, and social development (Healy, 1992). Others direct attention to Habermas' theory of communicative rationality (Campbell and Fainstein, 2003). Physical, design-based theories, such as New Urbanism and Neo-Traditional Development, among many others, consider the ultimate impacts of planning on society (Fainstein, 2005). New thinking about theoretical 
frameworks suggest that discretion, flexibility, and fluidity enable one to freely choose and work with many theories at once, avoiding the "either-or" compromises between one's use of theories. In this way circumstance, changing conditions, and needs of the constituency drive the solutions citizen and practicing planners choose to apply and adapt from planning frameworks (Ferreira, et al., 2009).

Social Science theoretical frameworks, such as PAR recognize personal experience (i.e., "Lived Experience") as an informative source of knowledge to promote, not only a better understanding of the relationship between physical place and the human condition, but also how knowledge and power influence place-based land use decision making (Aravot, 2002; Creswell, 2007). The richness and diversity of PAR's twentieth century roots in critical theory are its strength. My research and experience borrow from all three families of PAR (noted below). PAR's critical theory foundation in the work of Lewin, Fals Borda, Freire, and its evolution through Gaventa and Reason, provide ample linkages to emphasize the social, cultural, political, and economic implications of using PAR for land use planning. PAR and critical theorists remind us to "walk the walk," and share common ground by encouraging participants (and ourselves as researchers) to challenge assumptions and ideology.

\section{Three representative families of PAR nomenclature}

- Industrial Democracy Tradition (Kurt Lewin, Antonio Gramsci, Tavistock Institute)

- Organizational Development/Learning (Orlando Fals Borda, Paulo Freire, John Gaventa, Highlander Research \& Education Center)

- Workplace Democracy/Action Research in Education \& Participatory Research/Community Development/ Human Inquiry and Co-Operative Inquiry (Peter Park, John Heron, Peter Reason, John Rowan)

While there are many icons of PAR in the social sciences and human inquiry domains, my work is primarily informed by eight individuals: Antonio Gramsci, Paolo Freire, Jürgen Habermas, Max Horkheimer, Kurt Lewin, Orlando Fals Borda, John Gaventa, and Peter Reason. They stand out as a core group of social reformists who devoted their lives to equity, discourse, and action (Reason \& Bradbury, 2001). These PAR and critical theorists drew upon personal and lived experiences, including significant, life-changing events to inform and shape their writings on power, social interaction, democracy, and civics, and promoted social action through commentary and active critique.

Land use planning theory also shares common ancestral roots with several schools of PAR in critical theory. This overlap in ancestry is productive because it legitimizes a broad interpretation of knowledge and provides common conceptual frames. The spectrum of knowledge is broad, flexible, and diversified so that conventional sources of information and data can be considered side-by-side with local knowledge, lived experience, and conventional wisdom.

Civic empowerment and engagement in the land use planning process aligns exceptionally well with the redefinition of knowledge as a locally defined, recognizing lived experience, and employing an active learning approach to problem-solving. Conceptual frames are not limited to the traditional, positivist lens of hard, factual data. Multi-dimensional perspectives can be incorporated as well to include functional, interpretive, relational, affective, and reflective domains. The knowledge and conceptual frames generated by a group of people who meet to solve problems reflects real-time circumstances and involves consideration of social fabric, socio-economic conditions, relational issues between humans, and moral order (Park, et al. 1993; Park et al. 2001).

Collectively, their ideals of equity, discourse, dialogue, and action underlie PAR and stand as the pillars of my theoretical, professional, and applied research approach. The social justice aspects of PAR joined with evidence-based academic research help "level the playing field" through a partnership approach to community educational processes. The literal linguistics of the phrase, PAR, demonstrates movement forward and harmonizes with my diverse roles as researcher, planner, citizen, resident, and facilitator. I am an actor of Habermas' ilk in the role of connecting community to external networks to supply resources at the community's direction which help transform place. I embrace a broad and interdisciplinary view of PAR.

\section{Lesson \# 1: Integrating legal, ethical, and natural considerations}

Local decision-making and protection of ecologically sensitive landscapes benefit from a better understanding of the interrelationships between New York's unusual legal landscape and the complex ethical and natural considerations facing people and their land.

\section{New York's unusual regulatory landscape: state action, Home Rule, Dillon's rule, and local land use control}

In all 50 states, municipalities do not automatically or naturally have powers of self-government. State governments award or grant local government powers of self-government or Home Rule through a process of devolution and establish the delimitations for home rule authority. In the State of New York, Article 9 of the New York State Constitution endows a "Bill of Rights" for local governments (State of New York, Department of State, 2010). Embedded within Article 9, 
Sect. 2, are the defined list of Home Rule powers for local governments and these include the "rights, powers, privileges and immunities granted by the constitution" (State of New York, Department of State, 2010). In addition to other sources of authority and rights, New York State Law, in the form of Municipal Home Rule Law, elaborates on the Article 9 constitutional provisions of Home Rule. On the surface, it appears that local governments are delegated broad powers and local autonomy under the New York Constitution and the laws of the State of New York. However, power is restricted in scope (National League of Cities, 2010).

A keystone judicial interpretation that exists to counter-balance Home Rule in favor of the states is Dillon's Rule (Richardson, Jr., Zimmerman-Gough, \& Puentes, 2003; Richardson, Jr., et al., 2003.) Judge John F. Dillon, of Iowa, decided in 1868 that a state government's relationship to a political subdivision (local government) is a parental one. New York is one of 39 states that subscribes to Dillon's Rule and one of 31 that applies the rule to all municipalities. The rule clarifies a very narrow and strict construction of the breadth of local government powers, provides an approach for interpreting questionable jurisdiction between local governments and the state, and defers to the state if there is any reasonable doubt (Richardson et al. 2003; National League of Cities, 2010). New York is a Home Rule state, granting elevated levels of autonomy to local governments. However, it also employs Dillon's Rule, invoking the broad powers of the New York Constitution and the ability of the legislature to override and restrict municipal functions, such as land use planning, when it is in the best interests of the State (National League of Cities, 2010; Nolan, 1966; Nolan, 2001).

Further judicial interpretation of the Home Rule provisions was made in 1977 when the Adirondack Park Agency Act was legally challenged in the highest court in New York State, the Court of Appeals. In Wambat Realty Corp and v. State of New York, N.Y., 1910), the Adirondack Park Agency Act was upheld. The lawsuit argued that the APA Act preempted local planning and zoning authority and was an unconstitutional violation of Home Rule (Nolan, 1966; Nolan, 2001). The Court of Appeals' decision stated that it was New York State's purposeful intention to forestall local governments from controlling land use decisions to serve a supervening interest of the entire State. The Court stated, "To categorize as a matter of purely local concern the future of the forests, open spaces, and natural resources of the vast Adirondack Park region would doubtless offend aesthetic, ecological and conservation principles" (Wambat Realty Corp and v. State of New York, N.Y., 1910).

The New York Constitution broadly defined Home Rule in a general sense, and the Legislature preempted local decision-making on a case-by-case or issue basis when the matter was of critical importance to the People of the State of New York (Nolan, 1966; Nolan, 2001; Glennon et al. 2009). The Court of Appeals emphatically stated in its decision that, "...preserving the priceless Adirondack Park through a comprehensive land use and development plan is most decidedly a substantial State concern, as it is most decidedly not merely 119 separate local concerns..." (Wambat Realty Corp and v. State of New York, N.Y., 1910).

The Adirondack Park is a protected landscape where natural law has a vital role, but societal laws, enacted and changed from time to time, also govern the ecologically significant "green island" on the verge of the everexpanding Northeast Megalopolis (Lang, et. al., 2020). Experts agree that political and legal factors framing how Adirondack Park governments interact, contribute to making land use decision-making problematic (Terrie, 2008; Glennon et al. 2009, Golebiewski, 2020; Pastore, 2020). Specific flaws exist in the Adirondack Park Agency Act. Home Rule and Dillon's Rule are broadly interpreted.

Land use ethics that guide the conscience may be completely unrelated to what constitutes land use law. Legal "reality" is based on constitutional, judicial, administrative, and legislative interpretation in origin and effect. For example, sometimes land use laws and ethics appear to overlap. In other cases, there is conflict between legal and ethical obligations. History provides examples, many extreme, of the divergence between ethics and law when serving the best interests of a government. Nazi Germany instituted laws against the Jews, slavery was legal, children could work in factories. Governed by culture and religion, decency and fair play, and inculcated bias, citizen leaders and community officials may rarely see a strict separation of law and ethics. Adirondack Park stakeholders wrestle with ambiguous relationships between the "what is" reality of land use law and land ethics and perceptions of what "ought to be" when planning for the land.

The judicial system uses the symbol of the scales of justice to present the weighing of viewpoints in litigation. In this case, the balance between overarching concerns of the "state" and individual local government concerns tips in favor of the public interest repeatedly in the State of New York judicial system (Nolan, 1966). New York's judicial ruling confirming the Adirondack Park Agency Act (Land Use and Development Plan) does not excuse local governments from land use planning. On the contrary, the roles and responsibilities for local government planning are clearly established in the APA Act, enabling local governments to fully participate in a voluntary, tiered regional-local planning partnership. 


\section{Lesson \#2: Recognizing diverse types of land ownership}

Protected landscapes, such as the Adirondack and Catskill Parks, require merging science with politics, law, preferences, and property because where a mix of public and private land exists, so do landowners, and public decisions about the extent of public and private land development can be points of contention or consensus.

\section{"To categorize as a matter of purely local concern the future of the forests, open spaces, and natural resources of the vast Adirondack Park region would doubtless offend aesthetic, ecological and conserva- tion principles" (Wambat Realty Corp. v. State of New York, N.Y., 1977).}

According to the International Union for Conservation of Nature (IUCN) Definition, a protected area is "a clearly defined geographical space, recognized, dedicated and managed, through legal or other effective means, to achieve the long-term conservation of nature with associated ecosystem services and cultural values" (IUCN Website 2020). New York's Adirondack State Park is bounded by a figurative, legislatively drawn "Blue Line" that delineates the Park's strategic and ecologically important landscape features. The Blue Line binds this, the largest protected area within the Northern Appalachian/Acadian Eco-Region and within the contiguous US, to the jurisdiction of the Governor's Executive Department of the State of New York (State of New York, Adirondack Park Agency, 2010; Two Countries One Forest, 2009). Using a regional permitting process, Governor-appointed, and Legislatively confirmed decision-makers rely upon broadly stated policies and "antiquated" agency regulations to make case-by-case land use decisions affecting six million acres of private and public land (Glennon et al. 2009).

It is a generally held belief that New York State's Adirondack Park Agency Act (APA) protects communities from all forms of unwanted or uncontrolled development at the local and regional level within the political boundaries of the "Blue Line." The statute and permit facts do not support this myth. The swift adoption of the APA Act in the 1970's in theory, directed development away from critical habitat and environmentally sensitive areas, except for shorelines and roadsides (State of New York, Adirondack Park Agency Act, 1999; Adirondack Council, 1999; Adirondack Association of towns and villages 2009).

The three classifications of development [Hamlet (no significant restrictions for development), Moderate Intensity (five hundred buildings/square mile or one principal building on 1.3 acres) and Low Intensity (two hundred buildings/square mile or one principal building on 3.2 acres)] are all within the jurisdiction of local governments (State of New York, Adirondack Park Agency Act, 1999; Glennon et al. 2009). The APA may have jurisdiction for $20 \%$ of the large-scale projects, such as major resorts, commercial projects, and 100-unit subdivisions, but studies and statistics reveal that $80 \%$ of growth occurs in smallscale, incremental development projects on the local government watch (Ruzow Holland; 2010). This is because a state-local shared decision-making system is also in place, where Adirondack Park local governments interact and contribute to making land use decisions at the municipal level. Growth management and land use decisions (or indecisions) in the Adirondacks are influenced by the interactions between Adirondack local municipal governments and the State of New York, flaws in the Adirondack Park Agency Act (APA Act), and a misunderstanding of the Home and Dillon's Rules. Defining which public and private actions are in the "Best Interest of The People of the State of New York," is a social, cultural, and valueladen political process (Ruzow Holland, 2010).

The Adirondack Park Agency Act appears from permit analyses to demonstrate general protection of the Adirondacks from large-scale residential and commercial development. Permit statistics also point to increasing single family residential development around the lakes and ponds where land use controls are statutorily the weakest. Communities are experiencing increasing rates of new "high-end" residential construction, oversized additions, and the demolition/ conversion of resort and second-home properties to yearround retirement, weekend and "home-based" occupational uses. Many Park citizens and visitors are noticing that the lakeshores are being hardened with concrete and stone, aged trees, and shoreline vegetation removed, raised bed septic systems installed proximate to lakes and rivers. Farmlands are increasingly being developed for residential housing because their soils are suitable for on-site wastewater treatment and their vistas are more valuable than food or forage production. Forestlands are clear-cut in incremental acreage to avoid regulatory oversight. As a routine business practice, wealthy property owners are paying civil fines as a "cost of doing business" to comply with land use regulations and permit standards at the regional (APA) and local level.

Local government capacity to plan for private land use growth and development in the Adirondack Park has been a chronic concern since the Adirondack Park Agency Act was debated by the New York State Legislature in the 1960s and 1970s. It continues to be a growing concern. Some policymakers point to the high number of local governments engaged in planning as evidence of capacity. But the mere existence of a land use planning program may not reflect the actual decisions made, nor the adequacy of citizen empowerment or environmental stewardship. It does not reflect the quality of program design nor the equitable 
administration, enforcement, and system for quality assurance. And, in the Adirondack Park, the mere existence of a local planning program, even an APA Approved Local Planning Program, does not guarantee consideration and monitoring of the environmental impacts of development. There are no statutory "watchdogs" or Inspector Generals to monitor regulatory compliance (Ruzow Holland, 2010).

Citizens exist on either side of the decision-making table. Voluntary, citizen appointees serve on planning or zoning commissions and law places the decision-making in their hands. Whether or not they have the tools and capacity to implement the recommendations within their jurisdiction, those citizens applying for permits must lawfully abide by the agency decisions. In theory, and possibly in practice, voluntary citizen appointees serving on planning or zoning commissions are legally constrained by the existing language in the regulatory documents, i.e., comprehensive plan, zoning laws, site plan review. Fuzzy and ambiguous language will confound the process and lead to either narrow or broad interpretations to apply. For example, unless regulations and guidance provide direct and unambiguous language enabling consideration of the "larger picture," such as cumulative impacts, specific critical ecological systems, or unusual environmental impacts, decision-makers are legally constrained by the existing regulatory language (Ruzow Holland, 2010).

Furthermore, when one's neighbor is sitting across the table in a public meeting and you have been appointed as a citizen planner to institute the community land use code, it is difficult enough to look them in the eye and say "no, you can't do that." These are not arm's length relationships. If the land use laws are ambiguous, it is highly likely the board will decide in favor of the property owner. It is very unlikely that the board will prefer to table the matter, delay decisions, and spend the money on the municipal attorney to gain a legal interpretation. That is unless the applicant is contentious or wealthy and can afford to contest the decision-or just ignore the decision and do what they will. Who is going to verify or check their decision unless it is a contentious or controversial? In most cases the answer is no one (Ruzow Holland, 2010, 2013).

Time, attention, and financial resources may allow local governments to improve capacity, and periodically evaluate and update land use plans and regulations. In tandem, some level of periodic oversight or monitoring might also improve consistency of decisions and compliance with existing regulations. If $80 \%$ of the incremental and cumulative land use decision-making in the Adirondack Park is occurring at the local government level, then engaging in citizen-directed, knowledge-based, planning, and instituting accountability measures that improve the quality of land use policy developed by the community are critical to the functionality of the Adirondack Land Use and Development Plan (Ruzow Holland, 2010).

\section{Lesson \#3: Strategies for contested power: discovering shared ethics and values}

Taking the interest and time to understand what drives stakeholder social, political, and cultural dynamics can influence land use decision-making-confounding, limiting, or enhancing outcomes. A predisposition to work collaboratively to find common ground-at various levels of government—and the ability to set aside political differences in the public interest, can influence and enhance the desire to effectively plan (Ruzow Holland, 2010).

In protected areas, it was once thought that long-term residents' ability to steward the land could not match the fervor of external, western, and neo-colonial conservation interests. Conservation proponents see the importance of local land use planning as a critical component of landscape conservation. The Adirondack Council, the largest conservation organization in the Adirondack Park (with significant membership from around New York State), stated "Local planning... is not a luxury in the Adirondack Park. It is a necessity." (Adirondack Council, 2001, p. 7).

Not everyone agrees on a universal definition or approach to conservation. Local people living in the Adirondack Park appreciate nature and share concern for its ecological integrity and legacy, but agreement on how nature should be protected is not universal or unilateral. Stakeholder viewpoints about community-based natural environments are not at odds with conservation views, the community cares deeply about nature. Popular "...concern [for] the future of the forests, open spaces, and natural resources of the vast Adirondack Park region" is evident, but the approach to nature varies (Wambat Realty Corp and v. State of New York, N.Y., 1910, p. 2).

An historical record of diplomatic relations with public regulatory agencies and a predisposition to collaboration was discovered in the Willsboro Comprehensive Plan (2010) case study. An inclination for the township to work collaboratively with State agencies that was based upon public policy precedent established by town government over succeeding administrations was discovered. Willsboro benefitted from social and human equity capital in its relationship with the Adirondack Park Agency (APA) (Ruzow Holland 2010). Community experience with land use regulations was well developed, yet there were still factional stakeholder groups that chose not to take part in land use planning processes. Local government leadership (Town Supervisor and Planning Board Chair) showed commitment to land use planning (despite local government peer pressure to stay away from the APA and planning) as a key public 
priority and government service. Technical assistance and resources were provided by sympathetic Adirondack Park Agency Commissioners who had Willsboro's interests in mind (Ruzow Holland 2010). For more than forty (40) years, a constructive, proactive, cooperative strategy was reasonably successful and continues to engender a strong working relationship between the town and the Adirondack Park Agency on shared jurisdiction and project review.

However, in the recent planning project, one State agency brokered their power to withhold information and block procedural approvals that confounded the process. Funds were threatened with withholding unless the town conformed their land use plan to state policy expectations (not the APA jurisdictional ones) - that had no basis in law or regulation-even if these were contrary and possibly less stringent than local policies. The flexing of State power illustrates how tenuous and unbalanced the power relationships can be between State and local governments. Local governments are dependent on the financial resources of the State, and local-State rapport depends upon the parties involved. Coping strategies attempt to wrest local decision-making from the hands of New York State by the means available to local governments.

Shared decision-making relies on the tenets of capable and equally strong partners, also known as equity, discourse, and action (Reason \& Bradbury, 2001). In the history of the Adirondack Park Agency Local Planning Program, neither the municipalities nor the State have consistently proven to be strong partners, capable to plan or willing to share power. As a result, only a minority of Adirondack Park communities constructively collaborate with the APA.

There is a tension between local government reliance on the property tax to support essential services and land use decision-making (Currier, 1975; Fischel, 2013). If local governments derive their tax revenue from a property tax system that enables cash to flow into the government coffers based upon the value (and subsequent increasing number) of parcels within the taxing jurisdiction, there may not be an incentive for land preservation that promotes short term tax losses in favor of long-term increases in land value.

The drive to generate tax revenues is high on the local government agenda which is also steeped in crisis-to-crisis decision-making. Officials are bombarded with concerns about paying the steeply rising pension and health insurance bills for public payrolls, as well as capital costs for equipment and maintenance of roads, buildings, and infrastructure. Frustration is created by an aging infrastructure, limited resources, and an overwhelming responsibility to maintain facilities and services (Currier, 1975; Fischel, 2013). Under these circumstances, forward thinking is challenging unless it is proven in economic, return-on-investment terms. As a result, it may almost be impossible for economic reasons to say no to a subdivision permit application for more residential development or to imagine "growth" as secondary to landscape preservation. This is exacerbated by lack of access to knowledge and resources to consider and institute alternative futures that understand the value of natural amenities, preserve natural resources, or analyze economic trends and conditions. (Ruzow Holland, 2010).

The history of conservation in protected areas is fraught with failure because the values and ethics of the long-term residents are often ignored or reduced to their lowest common denominator by external, western, or neo-colonial conservation interests (Beinart, 1989; Purdy, 2020; Pierotti and Fogg, 2020). In the Adirondack Park, constituencies differ on many issues, and the mechanics of shared decision-making reveal unequal capacity and strength between the "state" and local communities. New York's Adirondack Park policy, ethics, and law are not always in harmony. Coming together to solve problems in an ethical and legal manner involves consideration of social fabric, socio-economic conditions, relational issues between humans, and moral order (Park et al. (1993)). With this understanding, change can occur in how one sees the landscape.

\section{Segway to Lessons \#4-10: the inflective PAR Paradigm for land use planning: linking planning, participation, and science}

Historically land is considered a highly valued and limited commodity. Mark Twain and Will Rogers captured this sentiment in their respective recommendation: "Buy land, they aren't making any more of the stuff" (Ayers, 1993). Merging land use planning, citizen participation, and science literacy using a PAR lens results in a modulation of the tone, purpose, and outcome of land planning. An inflective recasting or recharacterization using a PAR paradigm carries the potential to build capacity among citizen planners and local governments to recognize and carefully manage this fixed resource. Capacity is built because the convergence of land use planning, citizen participation, and science literacy create more thoughtful decision-making. It reflects an outgrowth of a consensual public process and a rigorous scientific base. The inflective PAR paradigm linking planning, participation, and science encourages civic leadership, civic responsibility, and civic engagement. Where popular consensus indicates that nature and working landscapes are highly valued, scientifically literate planning leadership and citizens in general have the confidence to institute land use change. Civic transformation is then demonstrated through specific and inclusive plan language, forming recommendations to preserve, protect, maintain, or mitigate impacts on community-based ecological systems and other aspects of the "commons," and evaluating implementation outcomes (Ruzow Holland, 2010, 2013, 2014). 
I call the inflective PAR paradigm the Trilogy, which is comprised of exemplary planning for land use, "bottom-up" citizen participation, and access to, and use of natural science. Within the Trilogy, the planning practitioner becomes a "tool," a technical facilitator. Community land and waterbased natural resources are the focal point of citizen-led planning and scientific knowledge is granted equivalent value to economic, demographic, and other data to inform decision-making. Paramount to this all, citizens, stakeholders, and elected representatives are equally empowered to lead and learn, discuss, and disagree, finding common ground to care for the land they say they love (Ruzow Holland, 2010, 2013, 2014).

\section{Lesson \#4: Reforming and modernizing land use planning practice}

Land use planning in the USA historically is a top-down process where enabling acts and pre-existing statutes devolve(d) authority from the state to regional and local governments and contributed to sprawl, exurban development, and inefficient transportation, housing, and energy use. Land use planning modernization and reform is needed to flexibly balance landscape-scale sustainability and conservation with demand for land development.

Land use planning, as it is practiced in the twenty-firsts century, is rooted in a diverse set of social, political, and economic theories and architectural movements. Affecting physical and human properties of place, planning is multidimensional, sometimes referred to as an "eclectic blend of design, civil engineering, local politics, community organization and social justice" (Campbell and Fainstein, 2003, p. 5). Scholars consider planning to be a science and an art, requiring technical and creative capacity (Birch, 2001; Ruzow Holland, 2010; MacDonald et. al., 2019).

The turmoil of the social revolution of the 1960s and the environmental movement of the 1960s and 1970s provided an important framework for the first Quiet Revolution in land use planning. This is also the timeframe when the Adirondack Park Agency Act, Vermont's Act 250, and a handful of other State-instituted regional growth management planning systems were enacted (Porter, 1993; Callies, 1994; Wickersham, 1994). The 1971 report to the Council of Environmental Quality by noted authors Fred Bosselman and David Callies, entitled The Quiet Revolution in Land Use Control defined Quiet Revolution and addressed the relationship of the title to the purpose of the report:

This country is in the midst of a revolution in the way we regulate the use of our land. It is a peaceful revolution, conducted entirely within the law. It is a quiet revolution, and its supporters include both conservatives and liberals. ... The ancient regime being overthrown is the feudal system under which the entire pattern of land development has been controlled by thousands of individual local governments, each seeking to maximize its tax base and minimize its social problems, caring less what happens to all the others. ... The tools of the revolution are new laws taking a wide variety of forms but each sharing a common theme-the need to provide some degree of state or regional participation in the major decisions that affect the use of our increasingly limited supply of land. The function of this report is to discuss and analyze these new laws and to try and predict and perhaps influence the course of this "quiet revolution." (Council of Environmental Quality 1971, p. 12).

Once again, 50 years later, Bosselman and Callies' statements take on insightful and visionary proportions as state enabling regulations, and the regional and local government regulations based upon them, have now been found to be the cause, in many instances, of sprawl, inefficient, inflexible, and unresponsive regulations, and the antithesis of the growing movement for sustainable, Smart Growth, and environmentally sensitive development (Salkin 2007). Rapid urbanization, unsustainable exurban development, automobile-dependent and sprawl-inducing land use-patterns, are the legacies of traditional planning (Vermont Department of Housing and Community Affairs, 2007; Salkin, 2007). The content of local and regional land use plans and regulations, including low-density recommendations and homogenous use restrictions (and the state enabling laws on which they are based), can unintentionally be the cause of sprawl. It is now understood that taken together they work against the growing movement for sustainable and environmentally sensitive development (Salkin, 2007).

Thankfully, history is prequel, and this recognition of planning's "mistakes" are now leading to what is called the second Quiet Revolution in planning. Climate resiliency, sustainability, healthy communities, walkability, and the Strong Towns Movement, are examples of popular planning terms and phrases that have replaced growth management as the buzzwords of the twenty-first century. The new generation of planning processes try to address these issues with new tools: GIS, drones, interactive platforms, broad public participation, web-based surveys, virtual meetings, natural science information, and unprecedented quantities of data. Circumstance, changing conditions, and needs of the constituency drive the solutions citizen planners and practicing planners choose to apply and adapt from planning frameworks (Ferreira, et al., 2009). In this sense, modern planning is a dynamic equilibrium between praxis and theory that enables planning to evolve as a science, rather than only as process to plan space (Batty, 1994). 
Barclay Hudson observed that planning evolved parallel to increasingly complex societal and economic systems and, as a result, it too became more complicated, recognizing the conflicts and uncertainties of modern life (Hudson et al. 1979). Frederick Law Olmstead, Jr., principally known for his role in designing New York's Central Park, published in 1914 a literature review documenting the American town planning movement in the late nineteenth and early twentieth centuries. Olmstead believed the movement showed early signs of what was to become planning theory's tenacious genetic streak towards trans disciplinarity (Olmstead 1914).

\section{Lesson \#5: Using Participatory Action Research}

Complex land use decisions are influenced by who participates, how knowledge is collected and analyzed, and who has access to that knowledge (Ruzow Holland 2013, 2014).

Land use planning can benefit from PAR as a methodological frame. Through PAR design, public processes can be altered to be more democratic, dialogue-driven, reflective, and thus transformative for participants. Reflective praxis, the idea that "a community [be] prepared to study the results of its own [social] action" is often missing from the land use planning practice (Lewin, 1997, p. 8). Collaborative development of knowledge and lived experience (Lesson \#2), reinforce lively and civil debate among many people (not just a chosen few). This leads to conversations about future land use in a climate of inclusive and constructive engagement. This builds ability and understanding in the citizenry. Reflection and examination of social action (or inaction) can reform land use planning in a constructive and thoughtful way (Ruzow Holland, 2010; Castella et.al., 2014; McAllister, 2020; Newman, et.al., 2020).

Debate and dialogue lead to the quest for information. PAR encourages the need to "know" and understand. This can motivate citizens to collect and analyze information, including scientific data. Having unlimited citizen access to information and technology is fundamental to PAR, since in many places information is held by the elite and the government agencies. Given access to resources, such as "best available" science, technology, and planning tools, even a small rural community in a protected area, can improve the quality of the planning outcomes. PAR shifts decision-making from the planner to the citizens. A collaborative development and selection of "knowledge" about a community's environment will result (Ruzow Holland, 2010).

If implemented carefully, PAR can substitute for planning situations where nominal or symbolic civic engagement was intended. In these cases, the traditional planning process often leaves citizens unhappy with the outcomes and unmotivated to implement the plan recommendations.
The plan results might change dramatically with decisionmaking for the project vested in the citizenry. An emergent process can develop elements of a thoughtful and effective plan based upon a careful balance of the ecological, social, and economic considerations of the community and the region. The PAR framework brings a distinctive advantage to land use planning through collaborative development of knowledge and consensus-driven decision-making (Ruzow Holland, 2010; Castella et.al., 2014; McAllister, 2020; Newman, et.al., 2020).

\section{Lesson \#6: Working with limited access to best-available science, technology, and planning resources}

Even with the framework of PAR to engage citizens in civic and social action, land use planning at the local government level is difficult and challenging, particularly in protected areas; inadequate resources add to this challenge. Fundamental limiting factors for effective and collaborative land use planning include political will and the availability of financial and technical resources. An added limiting factor is the availability and affordability of planners skilled in environmental planning and effective civic engagement.

In a natural resource amenity-rich area, the local government land use planning process should, at the minimum, rely upon a rigorous scientific analysis. Selecting interdisciplinary consulting planners whose training includes natural resource planning or environmental science is essential. In the best of circumstances, the local planning process would include PAR-based participation, and science literacy-and also involve professional planners acting as technical facilitators or figurative "tools" of the citizenry. Without the contributions of these disciplines, the planning process faces a risk that ecological systems and natural resources might be negatively affected —or completely ignored by the planning process and product (Holland 2013; Saarman, et al., 2013; Ruzow Holland, 2014; Kimpton, 2017; Park, et al., 2019).

Traditional land use planning places emphasis on the role of the private or public professional planner as the expert, and, granted they can supply most of the technical content, process, and project management services for a local planning program. When the emphasis is on the planner knowing "everything" the community will be relegated to the role of conformant. This planner-dominant approach may leave citizens with a limited and nominal role in the land use planning process. The result of the planner-dominant approach can be a feeble plan (or decision) of uneven quality with limited likelihood of implementation (Altshuler, 1965; Burby, et al. 1997; Mandelker, 2001). Led by an engaged, public-minded citizenry, roles and responsibilities for project management and content development are shared, and 
the planning process becomes collaborative, deliberative, and scientifically based, (Burby, et al., 1997; Hunnsicker, 2007). In design, content, and process, moving the location of substantial decision-making power from planner to citizen committee can shift the planning paradigm from a top-down to a bottom-up approach (Ruzow Holland 2013, 2014).

State governments should set aside generous financial resources to aid local governments so that they can prepare periodic analyses of their land use programs. A protected area's economic activity and tax base are theoretically constrained by a legislative act establishing park boundaries and limiting growth. Revenue sharing under the distributive tax system employed in New York and elsewhere should provide compensation for land use planning programs that meet ambitious standards. While it is possible to assemble substitute resources without State aid, it can be challenging. Few, if any local governments possess their own professional planners on staff. Only the wealthy, highly developed, or larger regional governments have a professionally credentialled (American Planning Association-AICP) planning staff dedicated exclusively to their land use work.

As a result of limited resources, sources of alternative help might include a regional university, public and nonprofit agencies, citizens with unique skills, and private funding. Alternative sources have their advantages and disadvantages, but their development takes time, energy and money that could have been spent working on addressing growth management and land use decisions.

In New York's Adirondack Park and Tug Hill Regions, the State of New York supplies technical planning aid to municipalities and counties as staff time permits and on a request basis. In the Tug Hill case, the political backlash from the establishment of the Adirondack Park Agency Act resulted in New York State developing a different land use planning approach through the Tug Hill Commission. The Tug Hill region is not bounded by a State imposed land use plan and staff technical assistance is provided in a geography free of the politics engendered within a State-regulatory framework. In the Adirondack Park, which preceded New York State establishing the Tug Hill Commission, the region is bounded by a mandatory regulatory framework (Hahn \& Dyballa, 1981). As noted previously, the political conflict that ensued may influence a municipalities' preference for technical assistance. While circumstances have improved and Park Agency staff is accessible and helpful, the aid comes in the context of the Adirondack Park Agency Act. In the Catskill Park, much of the geography is growthconstrained by the New York City Watershed Agreement. As a result, a consortium of watershed townships aggregates financial resources provided by New York State and the New York City Water Department to underwrite technical assistance to Catskill municipalities (Catskill Watershed Corporation, 2021). In all these places, the queue is long and staff time is limited so that communities either go without, hire engineers and other consultants to support growth management efforts at the local scale or use a combination thereof.

Modern planning in the USA is also a content rich endeavor enhanced by information technology. Financial resources can assure technical capacity such as planning equipment, software, training, and support. Technology to support land use planning is evolving rapidly and while the costs of technology are decreasing, to many communities, sharing services or budgeting for these expenses are constrained. Web-based decision support and voting systems, Wayfinding and other phone applications, Virtual Reality, Game Theory, Network Analysis, drones, videos, and newer modeling programs are now more readily available on the municipal market. Traditional methods of communication, including conflict management, consensus development, and participatory visioning are also getting new traction. The technical toolbox is getting larger, and hopefully more usercommunity friendly and affordable.

Without routine financial support, local governments within protected areas lag behind wealthier communities and are challenged to start up or maintain Geographic Information Systems, even if they cooperate to share services. And it is important that amenity-rich, protected areas have the advantages of GIS (and the next generation of mapping and analytic software) because they supply a valuable database and serve an important educational function-regardless of community scale. For example, Essex County, New York, host of the Adirondack High Peaks Region, has only recently developed a GIS system. Warren County, New York, in the Southern Adirondacks has benefitted from a GIS system and staff for more than 10 years. The existence of a Statewide GIS Clearinghouse and the Adirondack GIS User's Group are important resources and supportive of small-scale GIS applications and users. These resources do not substitute for local capacity.

Graphic depictions and visualizations of existing community attributes and scenario modeling of future conditions can be better understood by citizens using GIS and related tools. When the power of information technology is employed for the benefit of citizens in protected areas, they become better equipped to make wiser incremental and cumulative land use decisions about internationally important ecological systems and open space (Ruzow Holland, 2010).

\section{Lesson \#7: Using science to inform and enlighten the planning process}

Citizen participation in a local and regional land use planning promotes "buy-in" and follow through at all levels of implementation. Equally important are the "hard systems" of 
good planning and good science that also inform and shape the process (Burby 2003). One could be well meaning, and be concerned for the environment, but through a lack of understanding of ecological science, design practices and approaches, endorse an action contrary to good ecologically sensitive land management (Thompson 2004). The reality that is constructed by the community needs to be integrated with the hard systems of good science, shaped by the planning process (Pahl-Wostl 2005).

Conservation science is integral to making land use planning comprehensive in every landscape from urban, to suburban, to exurban and rural, as well as in protected areas. Scientists are needed in local planning for their expertise, scientific information, for their systematic approach, and for their role as a stakeholder. Conservation science as a discipline, contributes in three special ways to the development of a land use planning program. It contributes information and data to develop a base of knowledge from which planners and citizens make informed decisions. Conservation science supplies stakeholders and interest groups representing key landscapes rich in biodiversity requiring protection or preservation. Lastly, Conservation science provides technicians and experts to assist planners and citizens to interpret and understand both the data and landscapes in spatial and temporal terms relative to the dynamics and impacts of development. Richard Knight observed that conservation biologists and ecologists realized that within the USA, private lands are their next frontier (Knight, 1999). He stated, “...we are losing private lands to commercial and residential development at rates seldom equaled in history" (Knight 1999). Knight suggested that conservation biologists participate in local communities and "do the hard things...on the land, with honest conversations among stakeholders and property owners" (Knight, 1999).

Scientists and conservation interests can contribute ideas, knowledge, and multiple perspectives on current and future private and public land management within a community's authority. When part of the process, conservation scientists contribute ecological and science-based information in a systematic manner that can aid in the decision-making process (Baldwin et al). Listening to scientists speak about critical habitats, viewing maps depicting biodiversity "hotspots," and taking part in discussions about the threats to wildlife from specific kinds of development, encourage all stakeholders to consider science as a legitimate and essential pre-requisite for sound decision-making. Over time repeated involvement of conservation scientists in the process promotes seepage into the planning discourse. It also habitualizes participants not to forget conservation scientists as key stakeholders to help frame the planning process lest important or key properties are forgotten or not identified (Baldwin et al). If seated, represented, and respected at the table, a thread binds together conservation, ecology, and local planning on the ground to make private land use policy with incremental global impact.

Citizen planners and the public (who are landowners or adjacent property owners) are motivated to understand the science behind development and its impacts on the land. Ecological stewardship is supported by a scientifically literate citizen-led land use planning process. To accomplish planning objectives, scientific literacy requires full access to information, especially information technology, as an important, perhaps critical means to an end (not an end in itself). Accurate and current natural science information must be available and understandable to inform citizen debate and decisions (Cooper, et. al., 2007; Holland 2013; Kobori, et.al., 2016).

\section{Lesson \#8: Riding the coattails of popular movements.}

Public interest (and understanding) is served by connecting multi-scalar land use planning work to laypeople's understandings of "wildly popular movements of the times" (such as Biodiversity, Climate Change, Local Foods, Green Infrastructure, Sustainable Development, and Smart Growth).

Statutory-based land planning in the USA has survived for hundreds of years. Some experts suggest that the approach, goals, and larger worldview need to keep up and reflect changing demographic, geographic, economic, and social conditions (Airey and Doughty, 2020; Stoeglehner, 2020). Land use planning should continue to evolve and manifest attributes useful to society or become an archaic legal barrier to sustainable growth, inclusive communities, and the changing needs of an evolving civil society.

One might argue that popular movements can inform, ground, and guide community land use decisions because they are meaningful to various stakeholder groups (Ingra and Varady, 1996; Byner, 2001). The familiarity and popularity of movements and their specific lexicons can contribute to the preservation of land and land sequestration. Place-making, growth management, hazard mitigation, climate resilience, public health, equity, social justice, and environmental protection are familiar and popular issues that people care about. Green Infrastructure, Sustainable Development, and Smart Growth are also terms with divergent use, limited understanding, and wide popular appeal. A similar argument may be made for carbon-neutral, agriculture, or biodiversity issues. Add to this growing list phrases such as Bright Green, food security, extreme weather events, and pandemic (Steffen, 2009). For example, a rapid search using a Google search engine produced 290,000 definitive references for Green Infrastructure and 245,000 for Smart Growth.

Deliberately and consistently integrating relevant popular movements that impact ecological integrity into the iterative 
land use planning process is an important lesson learned. To this point, the American Planning Association in developing its evolving Comprehensive Plan Standards recognized the value of relevant, popular topics such as water quality, affordable housing, hazard mitigation, equity, and public health as essential ingredients in exemplary comprehensive plans (Godschalk and Rouse, 2015).

Linking land use planning to the popular movements of the times is not just faddish; it helps to connect and reinforce planning work to laypeople's understandings of ecology, economics, agriculture, and energy, etc. The goals of land preservation and consideration of future generations' needs, if embraced in an iterative land use planning process, can be expressed clearly in the recommendations section of the plan and in the implementing regulations. Embedding a process of dialogue and transactional understanding that takes advantage of popular movements of concern to local stakeholders enables guidelines, regulations, or criteria to be created from the recommendations that provide the community with a blueprint to follow. In this way incremental progress is made towards achieving land preservation goals.

\section{Lesson \#9: Recognizing human relationships with natural environments}

Stakeholder recognition of their personal relationship with natural environments and the place they inhabit (call home) enables diverse interests to engage in purposeful civic action.

"This is a town in the heart of Utah that believes we can begin to live differently, that the preservation of one's homeland is the preservation of the planet." (Tempest-Williams, 2005)

Conservation organizations employ the phrase coined by Dr. Rene Dubos, "Think Globally, Act Locally" as their modus operandi as they seek to preserve, protect, and connect strategic landscapes of ecological importance (Revkin, 2001). A convincing case is made by conservation scientists of the correlation between land transformation and ecosystem health, and this leads to conservation policy that promotes the set aside and protection of key lands through public acquisition and easement (Hasan et al., 2020). But all land cannot be practically set aside or economically sequestered from human impact or transformation. Limited funding, political will, and other factors, such as the private nature of real estate limit conservation to only a fraction of total land area. Some land is just not for sale. "Acting Locally" conservation interests, such as the Land Trust Alliance (a National Non-Profit Organization serving the USA), turn their attention to community conservation. Community-scale land use planning can play a critical role in responding to global change and can reorient the way a community reacts, responds to, and manages change (Hanna 2005). With understanding, change can occur in how one sees the landscape.

For some, protection of the landscape surrounding their home is the reason to become involved. Terry Tempest Williams relates a story of the fight for Castle Valley in Utah (Tempest-Williams, 2005). She relates, "Out of our shock, anger and affection for each other, the Castle Rock Collaboration was formed. We had no money. We had no power. We had only our shared love of home and a desire for dialogue with the open spaces that defined our town."

For others, it is a belief that nature needs a champion. William Cronon suggests that natural areas be contextualized as cultural landscapes that need protection in local plans and promoted as such to get local constituencies involved to steward these areas (Cronon 2005). Cronon states, "People work hardest and best when they believe themselves to be defending and nurturing the things they love most" (Cronon 2005).

If the strength of residents' and officials' convictions can be reinforced, then local governments may be the driving force for local conservation (Colburn 2006). Local government action can be "more democratic and rational" (Colburn 2006). In its simplest form, recommendations in local government planning documents, such as the development of a green infrastructure plan and other open space provisions, promote a pragmatic form of local conservation. "Thus, if anything, municipalities that succeed in their competitive environment by keeping residents and attracting new ones have shown they are highly skillful bargainers-highly adaptive, pragmatic stewards of local aesthetics" (Colburn 2006). Colburn also suggests capturing local government's interest (and subsequent involvement and commitment) by demonstrating the connection between their involvement in conservation activities and popular notions of natural resources as amenities in residential communities. Pragmatic conservation in the interests of high property tax revenues and intrinsic values may substitute for abstract, eco-centric motives, but it is conservation, nonetheless.

Citizens enter a meeting room with the intent to take part in a local land use planning program, and bring with them a wealth of knowledge, a morality that establishes some value for nature and a relationship with their neighbors and the landscape. Peter Park draws a wonderful visualization of transformational community action, including planning, when he states ".... what people bring to [this] enterprise as everyday knowledge-their intimate familiarity with their environment, their knowledge of one another as members of a community, and their critical consciousness that their lives can change for better-and transforms that knowledge into a more organized form, turning common sense into good sense (Gramsci, 1971)" (in Reason and Bradbury 2001). 


\section{Lesson \#10: Educated and informed citizens are a force for nature}

Educated and informed citizens who understand the role ecology plays in place-based land use planning can serve as an intervening force in rapid land use change.

Land use planning is conducted in an environment that involves social and economic systems, as well as biological ones (Pierce et al., 2005). Landscape ecology must insist on equal standing. The contribution of conservation science to the evaluation and analysis of land use decisions at the local and regional levels provides an early opportunity to educate and inform local government officials and stakeholders about natural resource amenity development, including infrastructure, such as roads, second-home development, and supportive services - and their relative location in rural, scenic waterfront, and back-country locations (Ruzow Holland, 2010; Wu, 2019; Jennings, et.al., 2020).

Rather than happening in somebody else's back yard, these developments (both incremental and substantive) are increasingly happening locally. The proliferation of natural resource amenity-based development has a unique way of focusing stakeholder and citizen attention on land use regulations. Citizens require scientific knowledge to understand the implications of road networks and their effect on traffic safety, animal mortality and human/wildlife interactions, and water pollution (Baldwin et al).

The secondary consequences of opening large tracts of forest or agricultural lands to housing development will also invite invasive species, all-terrain vehicles, loose dogs, and cats, making what was once a quiet, pastoral, or forested landscape into a busy suburban neighborhood. Conservation Science, spatial modeling and visualization techniques can help educate citizens to understand what happens in physical and temporal dimensions when amenity development infrastructure is introduced in various scenarios. Studies show that at the watershed scale, alternative, compact forms of development produce smaller (hydrological) impacts, but compact forms of development do not produce as much revenue for local governments (Bosch et al. 2003). "Faced with increasing expenditures to serve growing populations, many local governments may have financial incentives to allow low density development" (Bosch 2003). Inviting scientists to the table to share knowledge with citizens and officials about the options and consequences of open space development enables a dialogue about economic, social, and ecological impacts that may not happen in alternative circumstances. As a result, mitigating recommendations may be introduced into comprehensive land use planning before development is on the doorstep.

If the strength of residents and officials' conviction can be reinforced through scientific knowledge, then local governments may be the driving force for local conservation (Colburn 2006). Local government action can be "more democratic and rational" (Colburn 2006). In its simplest form, recommendations in a land use plan, such as the development of a green infrastructure plan and other open space provisions, promote local conservation. "Thus, if anything, municipalities that succeed in their competitive environment by keeping residents and attracting new ones have shown they are highly skillful bargainers-highly adaptive, pragmatic stewards of local aesthetics" (Colburn 2006). Colburn suggests capturing local government's interest (and subsequent involvement and commitment) by demonstrating the connection between their involvement in conservation activities and popular notions of natural resources as amenities in residential communities. Pragmatic conservation in the interests of high property and intrinsic values may substitute for abstract, eco-centric motives, but it is conservation, nonetheless (Ruzow Holland, 2010; Holland 2013).

\section{Conclusion}

Since modern settlement began in the late eighteenth century, factional economic and political interests joined with ecological ones to determine how Adirondack and Catskill Park private and public lands are used (Terrie, 2008). The Adirondack and Catskill Parks, and the Northern Forest Regions to the east, are real estate markets and popular destinations for eighty-four million people residing in New York City, Boston, Montreal, and Toronto (Adirondack Association of Towns and Villages, 2009). Expedient access by interstate systems and air travel allows for longer tenure (and ultimately permanent relocation). Starting in the 1970s, technological innovations such as the internet, cellular telephones, and computers started blurring the line between home and workplace. These innovations enabled seasonal and second-home property owners to extend their stay at "camp" and work from their now year-round resort properties (Clarkson University, 2010). The comforts and conveniences of modern lifestyles are now the norm in the countryside and the preferred lifestyle can be accommodated locally. Increasing values of real estate, growing incomes and wealth in metropolitan areas make property in natural resource based, amenity-rich places such the Northern Forest, Adirondacks, and Catskills even more desirable and affordable to affluent urbanites and suburbanites. During 2020, and now into 2021, news media are filled with stories of how the COVID-19 pandemic continues to create a surging and unparalleled temporary and, in many cases, a permanent exodus from the Northeast Megalopolis, crowding the Adirondacks, Champlain Valley, Catskills, and Northern 
Forest Region with families fleeing their urban and suburban residences. During 2020 and now into 2021, this trend is producing a dramatic upswing in migration-both temporary and permanent. As a result, demographics, land use, service demand, and public health disparities are rapidly changing - and research on the environmental and community impacts of these changes will need to catch up. "Tomorrow" is now a rapidly changing paradigm.

I conclude with the origins of the phrase embedded in the title to this monograph. Throughout his long life, folk icon Pete Seeger showed the value of narrative, "lived experience," and social action. In the 1960s and later in the mid1970s, his Hudson River song, "How Are We Going to Save Tomorrow?" queried the listeners to "hear" the relationship between access to knowledge, place, community, and political action (Pareles, 2014). The song and the pragmatic idealism of the environmental movement evolved contemporaneously as the fight moved from nuclear power to PCB pollution in the Hudson-and the song's message remained: we need to get to work to save tomorrow.

Envisioning a "tomorrow" conceived within our imagination of today, with a pandemic not nearly over, is incredibly challenging, and some may say no longer be possible. In a 2008 interview, Pulitzer Prize winning Poet Jorie Graham remarked, “... it is going to take some work to help people 'see' in their mind's 'eye' that far off horizon many generations beyond their own time, a time towards which they are going to have to try to take a leap of faith-and a leap which involves deep sacrifice at that. But I would not be making the effort to answer you...., if I did not believe we still had that chance. A real chance. (Graham, 2008).

\section{References}

Adelman C (1993) Kurt Lewin and the origins of action research. Educational Action Research 1(1):7-24

Adirondack Association of towns and villages. (2009). Adirondack Park Regional Assessment Report. Adirondack Association of Towns and Villages, Mayfield, NY, 12117.

Adirondack Council. (1999) After the fact: the truth about environmental enforcement in the Adirondack Park an analysis of the Adirondack Park Agency's Enforcement Programs. https://www. adirondackcouncil.org/vs-uploads/special_reports_archive/13419 42164_After_the_Fact.pdf

Adirondack Council. (2001). Falling further behind the truth about environmental enforcement in the Adirondack park. A progress report on the Adirondack Park Agency's Enforcement programs. Elizabethtown, NY.

African Studies, 15(2), 143-162.

Altshuler A (1965) The goals of comprehensive planning. J Am Plann Assoc 31(3): 186

American Planning Association, Planning Timeline https://www.plann ing.org/timeline/

Anderson, J. R. (2008). The importance of Maine for ecoregional conservation planning.
Aravot I (2002) Back to phenomenological placemaking. J Urban Des 7(2):201-212

Ayers, Alex (1993). The Wit and Wisdom of Will Rogers: An A-to-Z Compendium of Quotes from America's Best-Loved Humorist. Plume; 1st Edition (December 1, 1993)

Baldwin, R. F., Trombulak, S. C., Beazley, K., Reining, C., Woolmer, G., Nordgren, J. R., \&

Batty M (1994) A chronicle of scientific planning: the Anglo-American modeling experience. J Am Plan Assoc 60(1):7

Beinart, W. (1989). Introduction: the politics of colonial conservation. Journal of Southern

Birch EL (2001) Practitioners and the art of planning. J Plan Educ Res 20(4):407-422

Bosch DJ, Lohani VK, Dymond RL, Kibler DF, Stephenson K (2003) Hydrological and fiscal impacts of residential development: Virginia case study. J Water Resour Plan Manag 129(2):107-114

Brown G, Raymond C (2007) The relationship between place attachment and landscape values: toward mapping place attachment. Appl Geogr 27(2):89-111

Brown C (2011) Advancing transdisciplinary action research in rural Pennsylvania: the case for plural design in the Susquehanna River Town. Landsc J 30(1):88-105

Burby RJ (2003) Making plans that matter. J Am Plann Assoc 69(1):33

Burby RJ, May PJ, Berke PR, Dalton LC, French SP, Kaiser EJ (1997) Making governments plan: state experiments in managing land use. The John Hopkins University Press, Baltimore, MD

Bryner GC (2001) Gaia's wager: environmental movements and the challenge of sustainability. Rowman \& Littlefield

Callies, D. L. (1994). The quiet revolution revisited: a quarter century of progress. The Urban Lawyer, 197-213.

Campbell S, Fainstein SS (2003) Readings in planning theory, 2nd edn. Blackwell Publishing, Malden, MA

Carlson MC, Kaepke MP, Hanson MP (2011) From pits and pikes to lakes and landscapes. Landsc J 30(10):35-52

Castella JC, Bourgoin J, Lestrelin G, Bouahom B (2014) A model of the science-practice-policy interface in participatory land-use planning: lessons from Laos. Landsc Ecol 29(6):1095-1107

Catskill Watershed Corporation, (2021) Retrieved from: https://cwcon line.org/history-of-the-nyc-water-supply/

Chanse V (2011) Contexts and complexities; a case study in evolving participatory watershed stewardship. Landsc J 30(1):121-132

Clarkson University, (2010) Adirondack initiative for wired work survey report released February 2010. https://www.clarkson.edu/ sites/default/files/2018-07/ADK_SURVEY_2010.pdf

Colburn JE (2006) Localism's ecology: protecting and restoring habitat in the suburban nation. Ecol Law Quart 33(945):945-101

Cooper, C. B., Dickinson, J., Phillips, T., \& Bonney, R. (2007). Citizen science as a tool for conservation in residential ecosystems. Ecology and society, 12(2).

Council on Environmental Quality. (1971). The quiet revolution in land use control. Washington, DC: Superintendent of Documents, Government Printing Office: Bosselman, F, Callies, D.

Creswell JW (2007) Qualitative Inquiry and research design, 2nd edn. Sage, London

Cronon, W. (2005). Saving the land, we love: conservation and American values: the land trust alliance special report: exchange 25 th Anniversary Issue 28(4). http://www.lta.org/publications/excha nge/special_issue.html

Currier BA (1975) Exploring the role of taxation in the land use planning process. Ind LJ 51:27

Fainstein S (2005) New directions in planning theory. Rutgers University, New Brunswick, NJ

Ferreira, A., Sykes, O. \& Batey, P. (2009). Planning theory or planning theories? The Hydra Model and its implications for planning 
education. Journal for Education in the Built Environment, Vol. 4, Issue 2, December 2009 pp. 29-54 (26)

Firouzmakan S, Daneshpour SA (2015) Promotion quality of life by increasing place attachment in public places. Procedia Soc Behav Sci 201:418-428

Fischel, W. A. (2013). Fiscal zoning and economists' views of the property tax. Available at SSRN 2281955.

Freire, P. (1970-2009). Pedagogy of the oppressed. New York, NY: Continuum. International Publishing Group.

Gaventa J (1982) Power and powerlessness quiescence and rebellion in an Appalachian Valley. University of Illinois Press, Urbana, IL

George, C., Tucker, R. E., Klein, J. D., Bond, H. E., \& Amodeo, M. (2020). The Adirondack Chronology.

Glennon R (2009) A land not saved. In: Porter WF, Ericson JD, Whaley RS (eds) The great experiment in conservation, voices from the Adirondack Park. Syracuse University Press, Syracuse, NY, pp 265-281

Godschalk, D., Rouse, D. (2015). Sustaining places: best practices for comprehensive plans. PAS Report 578. American Planning Association

Golebiewski, M. (2020). George D. Davis Papers, 1968-1994.

Graham, J. (2008) Interview. Retrieved from: https://poets.org/text/ imagining-unimaginable-jorie-graham-conversation

Gramsci A (1971) Selections from prison notebooks. International Publishers, New York, NY

Habermas J (1970) Knowledge and human interest. Beacon Press, Boston, MA

Hahn AJ, Dyballa CD (1981) State environmental planning and local influence: a comparison of three regional natural resource management agencies. J Am Plann Assoc 47(3):324-335

Hall P (2014) Cities of tomorrow: an intellectual history of urban planning and design since 1880. John Wiley \& Sons

Hanna KS (2005) Planning for sustainability: experiences in two contrasting communities. J Am Plann Assoc 71(1):27

Hasan, S. S., Zhen, L., Miah, M. G., Ahamed, T., \& Samie, A. (2020). Impact of land use change on ecosystem services: a review. Environmental Development, 100527.

Healey P (1992) Planning through debate: the communicative turn in planning theory. The Town Planning Review 63(2):143-162

Heron J, Reason P (2001) The practice of co-operative inquiry: research 'with' rather than 'on' people. In: Reason P, Bradbury H (eds) Handbook of action research: participative inquiry and practice. Sage Publications, London, pp 179-188

Hudson B, Galloway TD, Kaufman JL (1979) Comparison of current planning theories: counterparts \& contradictions. J Am Plann Assoc 45(4):38

Hunnsicker, P. (2007). A citizen's guide to influencing local land-use decisions, Brainerd, MN: Minnesota Waters

Ingra, H., \& Varady, R. (1996). Empowering grassroots linkages. Arid Land.

IUCN Website (2020). IUCN 2008 definition protected areas https:// www.iucn.org/theme/protected-areas/about

Jennings MK, Haeuser E, Foote D, Lewison RL, Conlisk E (2020) Planning for dynamic connectivity: operationalizing robust decision-making and prioritization across landscapes experiencing climate and land-use change. Land 9(10):341

J Airey, J., \& Doughty, C. (2020). Rethinking the planning system for the 21st century. Policy Exchange, London, https://policyexch ange.org.uk/publication/rethinking-the-planning-system-for-the21 st-century.

Kimpton A (2017) A spatial analytic approach for classifying greenspace and comparing greenspace social equity. Appl Geogr 82:129-142

Knight RL (1999) Private lands: the neglected geography. Conserv Biol 13(2):223-224
Kobori H, Dickinson JL, Washitani I, Sakurai R, Amano T, Komatsu N, Miller-Rushing AJ (2016) Citizen science: a new approach to advance ecology, education, and conservation. Ecol Res 31(1):1-19

Lake Champlain Basin Program, (2021) Retrieved from: https://www. lcbp.org/

Lang RE, Lim J, Danielsen KA (2020) The origin, evolution, and application of the megapolitan area concept. Int J Urban Sci 24(1):1-12

Lewin K (1997) Resolving social conflicts field theory and social science. American Psychological Association, Washington, D.C.

Lien LL (2009) Home as identity: place-making and its implications in the built environment of older persons. Housing and Society 36(2):149-170

McAllister, G. (2020). Participatory action research: challenges and rewards in fifteen field lessons. In the Companion to peace and conflict fieldwork (pp. 189-206). Palgrave Macmillan, Cham.

MacDonald J, Branas C, Stokes R (2019) Changing places: the science and art of new urban planning. Princeton University Press

Mandelker DR (2001) Fred Bosselman's legacy to land use reform. Journal of Land Use and Environmental Law 17(1):11

Mann WA (1993) Landscape architecture: an illustrated history in timelines, site plans and biography. John Wiley \& Sons

National League of Cities. (2010). 1301 Pennsylvania Avenue NW Suite 550, Washington, DC, 20004. http://www.nlc.org/about_ cities/cities_101/153.aspx

Newman G, Shi T, Yao Z, Li D, Sansom G, Kirsch K, Horney J (2020) Citizen science-informed community master planning: land use and built environment changes to increase flood resilience and decrease contaminant exposure. Int J Environ Res Public Health 17(2):486

Nolan, J.R. (1966). Accommodating Home Rule in State Land Use Reform. American Planning Federation, Planning Advisory Service Report Number 462/463, Modernizing State Planning Statutes, The Growing Smart Working Papers.

Nolan JR (2001) Well grounded, using local land use authority to achieve smart growth. Environmental Law Institute, Washington, D.C.

Nolan JR, Salkin PE (2010) Practically grounded: convergence of land use law pedagogy and best practices. J Leg Educ 60:1-49

Northern Forest Center, (2021) Retrieved from: https://northernforest. org/programs/overview

Olmsted, Jr. F. L. (1914). The town-planning movement in America. In Carol Aronovich (Ed.). Housing and town planning, the Annals 51(pp.172-181). Philadelphia, Pa. American Association of Political and Social Sciences

Orono, ME: Margaret Chase Policy Center, University of Maine.

Pahl-Wostl C, Hare M (2004) Process of social learning in integrated resources management. J Comm Applied Soc Psychol 14:193-206

Pahl-Wostl C (2005) The implications of complexity for integrated resources management. Environ Model Softw 22:561-569

Pahl-Wostl C (2007) The Implications of complexity for integrated resources management. Environ Model Software 22:561-569

Palermo PC, Ponzini D (2015) Place-making and urban development. Routledge, New York, NY

Park M, Derrien M, Geczi E, Stokowski PA (2019) Grappling with growth: perceptions of development and preservation in fasterand slower-growing amenity communities. Soc Nat Resour 32(1):73-92

Park P (2001) Knowledge and Participatory Research. In: Reason P, Bradbury $\mathrm{H}$ (eds) Handbook of action research: participative inquiry and practice. Sage Publications, London, pp 81-90

Park, P., Brydon-Miller, M., Hall, B., \& Jackson, T. Editors. (1993). Voices of change: participatory research in the United States and Canada. Westport, Connecticut: Bergin \& Garvey. 
Pareles, J. Jon. (January 29, 2014). Pete Seeger, champion of folk music and social change, dies at 94 . New York Times

Pastore, C. L. (2020). Battles of the North Country: wilderness politics and recreational development in the Adirondack State Park, 1920-1980.

Pierce SM, Cowling RM, Knight AT, Lombard AT, Rouget M, Wolf $\mathrm{T}$ (2005) Systematic conservation planning products for landuse planning: interpretation for implementation. Biol Cons 125:441-458

Pierotti R, Fogg BR (2020) Neocolonial thinking and respect for nature: do indigenous people have different relationships with wildlife than Europeans? Ethnobiology Letters 11(1):48-57

Porter DR (1993) State growth management: the intergovernmental experiment. Pace 1 Rev 13:481

Purdy, D. D. (2020). Green Gatekeepng: colonial conservation and the Jemez Principles (Doctoral dissertation, Northern Arizona University).

Purswani E., Pathak B., Kumar D., Verma S. (2020) Land-use change as a disturbance regime. In: Shukla V., Kumar N. (eds) Environmental concerns and sustainable development. Springer, Singapore. https://doi.org/10.1007/978-981-13-6358-0_6

Reason P, Bradbury H (2001) Handbook of action research: participative inquiry and practice. Sage Publications, London, UK

Revkin, Andrew C. (June 6, 2011). "A 'Despairing Optimist' Considered Anew". The New York Times.

Richardson, Jr., J.J., Zimmerman-Gough, M., Puentes, R. (2003). Is Home Rule the answer? Clarifying the influence of Dillon's rule on growth management. The Brookings Institution Center on Urban and Metropolitan Policy. Washington, D.C. http://www. brookings.edu/reports/2003/01metropolitanpolicy_richardson. aspx

Ruzow Holland, A. H. (2010). Participatory planning for a promised land: citizen-led, comprehensive land use planning in New York's Adirondack Park (Doctoral dissertation, Antioch University).

Ruzow Holland A (2013) Equity, discourse, and action: an inflective paradigm linking planning, participation, and natural science. Freudenburg, A Life in Social Research. Emerald Group Publishing Limited, In William R

Ruzow Holland AH (2014) Citizen-led, comprehensive land use planning in New York's Adirondack Park. Rural Soc 23(2):133-150

Saarman E, Gleason M, Ugoretz J, Airamé S, Carr M, Fox E, Vasques $\mathbf{J}$ (2013) The role of science in supporting marine protected area network planning and design in California. Ocean Coast Manag 74:45-56

Salas RN, Shultz JM, Solomon CG (2020) The climate crisis and COVID-19-a major threat to the pandemic response. New Eng J Medicine 383(11):e70

Salkin PE (2007) Squaring the circle on sprawl: What more can we do? Progress Toward Sustainable Land Use in the States. Widener Law J 16(3):787-837

Schroth O, Hayek UW, Lange E, Sheppard SRJ, Schmid WA (2011) Multiple-case study of landscape visualizations as a tool in transdisciplinary planning workshops. Landsc J 30(1):53-71
State of New York Adirondack Park Agency (1999) Adirondack Park Agency Act. Ray Brook, NY

State of New York Adirondack Park Agency (2009) APA Annual Report 2009. Ray Brook, NY

State of New York, Department of State. (2010). New York State Constitution http://www.dos.state.ny.us/info/pdfs/Constitution.pdf

State of New York, Adirondack Park Agency (2010) Website: http:// www.apa.state.ny.us/About_Park/more_park.html

Steffen, A. (2009). Bright green, light green, dark green, gray: the new environmental spectrum. World changing, 27.

Stoeglehner G (2020) Strategicness-the core issue of environmental planning and assessment of the 21st century. Impact Assessment and Project Appraisal 38(2):141-145

Tempest-Williams T (2005) The open space of democracy: the land trust alliance special report. Exchange 25th Anniversary Issue 28(4). http://www.lta.org/publications/exchange/special_issue. html

Terrie, P. G. (2008). Contested terrain: a new history of nature and people in the Adirondacks. Syracuse University Press.

Thering S (2011) A methodology for a scholarship of transdisciplinary action research in the design professions; Lessons from an Indian Country initiative. Landsc J 30(1):131-147

Thering S, Chance V (2011) The scholarship of transdisciplinary action research: toward a new paradigm for the planning and design professions. Landsc J 30(1):6-18

Thompson RH (2004) Overcoming barriers to ecologically sensitive land management.: conservation subdivisions, green developments, and the development of a land ethic. J Plan Educ Res 24:141-153

Two Countries One Forest (2009). Tug hill: embracing sustainability, conservation and connectivity. Meet $2 \mathrm{C} 1$ forest partners- a network of people creating a network of conserved lands Newsletter, July 2009. Retrieved from: http://www.2c1forest.org/en/resou rces/resources.html

Two Countries One Forest (2021) Retrieved from: https://2c1forest.org/ Vermont Department of Housing and Community Affairs. May 2007. Vermont land use education and training collaborative: essentials of local land use planning and regulation, Retrieved from: www. dhca.state.vt.us/Planning

Wambat Realty Corp. v. State of New York, N.Y., Lexis 1910. (N.Y. Ct. App. 1977)

Watson MF, Bacigalupe G, Daneshpour M, Han WJ, Parra-Cardona R (2020) COVID-19 interconnectedness: health inequity, the climate crisis, and collective trauma. Fam Process 59(3):832-846

Web site: http://denali.asap.um.maine.edu:16080/mcs/?q=node/1169

Wickersham JH (1994) The quiet revolution continues: the emerging new model for state growth management statutes. Harv Envtl 1 Rev 18:489

Wu J (2019) Linking landscape, land system and design approaches to achieve sustainability. J Land Use Sci 14(2):173-189

Publisher's note Springer Nature remains neutral with regard to jurisdictional claims in published maps and institutional affiliations. 